\title{
COMMENT
}

\section{THE APPLICABILITY OF MIRANDA TO RETRIALS}

The United States Supreme Court in Johnson v. New Jersey ${ }^{1}$ held that the exclusionary rule of Miranda $v$. Arizona ${ }^{2}$ would be "available only to persons whose trials had not begun as of June 13, 1966," 3 the date of the Miranda decision. The Johnson Court decided that Miranda's application should be limited so that it would not upset either final judgments or judgments in cases "still pending on direct appeal [from] trials preceding Escobedo and Miranda," " that is, nonfinal judgments. The Court, however, has not spoken directly to the issue of whether Miranda should apply in retrials, granted either on direct appeal or on collateral attack, when the case was reversed on grounds other than violation of the rules of Miranda..$^{5}$ Six of the state courts which have faced this issue have decided that the exclusionary

1384 U.S. 719 (1966).

2384 U.S. 436 (1966).

3384 U.S. 734 (1966). The Court likewise held that the rule of Escobedo v. Illinois, 378 U.S. 478 (1964), would apply only in trials beginning after the date of Escobedo.

4384 U.S. 733. For discussion of the wisdom of prospective rulings by the Supreme Court, see Mishkin, Foreword: The High Court, The Great Writ, and the Due Process of Time and Law, 79 HARv. L. REv. 56, 57-58 (1965); The Supreme Court, 1965 Term, 80 HARv. L. REv. 125, 129-41 (1966) ; Comment, Linkletter, Shott, \& the Retroactivity Problem in Escobedo, 64 MrcH. L. REv. 832 (1966). The Johnson court found "no jurisprudential or constitutional obstacles" to holding Miranda's standards to apply prospectively only. 384 U.S. at 733.

5 This question is most urgently presented in the situation in which the retrial was granted before Miranda was handed down. The language quoted in the text accompanying note 4 supra lends itself to the argument that a retrial granted after Miranda does not raise a similar problem. Such an interpretation, however, would create the anomaly of not applying Miranda to retrials granted after other retrials to which Miranda might apply. Hence, for purposes of this discussion, it is assumed that the "cases pending on appeal" statement refers only to judgments not reversed on Miranda grounds.

A distinction between cases in which a retrial is granted on direct appeal and those in which a retrial is granted on collateral attack might be attempted on the issue of finality. In the former cases the convictions are not yet final when the retrial is granted, while in the latter cases direct review has been exhausted and the convictions are considered final. Under Johnson, Miranda does not apply to decisions already final at the time of the Miranda decision. However, in both situations the defendant must be given a new trial as if there had been no previous trial. See note 18 infra. From this viewpoint, the finality distinction is not significant.

A second possible distinction is that retrials following collateral attack are likely to examine more distant events and involve greater evidentiary burdens in retrial than ones resulting from direct attack. However, the appellate process can be greatly prolonged. If a distinction is to be made between more and less distant cases, then there should be both retrials resulting from collateral attack and those from appellate review on each side of the dividing line. 
principle of Miranda shall be applied in retrial; ${ }^{6}$ the United States Courts of Appeals for the Third and Fifth Circuits have also decided that Miranda is applicable. ${ }^{7}$ Four state courts have taken the opposite position, challenging Miranda's applicability on retrial. ${ }^{8}$

The Court in Miranda, anxious to protect the fifth amendment privilege against self-incrimination, held that before there can be any in-custody interrogation of the accused, the accused must be advised of his constitutional rights and of the potential use of his statements. In order to ensure the effectiveness of these warnings, the Court demanded the use of certain "procedural safeguards" 9 or of procedures demonstrated by the state to be the equivalent thereof. ${ }^{10}$ In the event that any one of the procedures is not followed, the subsequent statements of the accused are summarily to be excluded at trial upon the motion of the defendant-the statements are to be excluded without inquiry into whether the procedural deficiency actually impaired the voluntariness of the statements. ${ }^{11}$ State and federal cases prior to Miranda and Escobedo $v$. Illinois, ${ }^{12}$ the forerunner of Miranda, had not set such stringent requirements for the protection of the accused's fifth amendment privilege. ${ }^{13}$ The previous measure of admissibility was the "voluntariness test" which examines the "totality of circumstances"

6 State v. Brock, 101 Ariz. 168, 416 P.2d 601 (1966) ; People v. Doherty, - Cal. 2d -, 429 P.2d 177, 59 Cal. Rptr. 857 (1967) ; State v. Ruiz, - Hawaii -, 421 P.2d 305 (1966); Creech v. Commonwealth, 412 S.W.2d 245 (Ky. 1967) ; State v. Bradshaw, - R.I. -, 221 A.2d 815 (1966) ; State v. Shoffner, 31 Wis. 2d 412, 143 N.W.2d 458 (1966).

7 Gibson v. United States, 363 F.2d 146 (5th Cir. 1966) ; United States ex rel. Pierce v. Pinto, 259 F. Supp. 729 (D.N.J. 1966), aff'd per curiam, 374 F.2d 472 (3d Cir. 1967).

With the exception of People v. Doherty, - Cal. $2 \mathrm{~d} \rightarrow, 429$ P.2d 177, $59 \mathrm{Cal}$ Rptr. 857 (1967), the cases holding Miranda applicable on retrial do so without discussion of the issue. In Doherty, the California Supreme Court relied on a refutation of the contrary position, rather than on affirmative reasoning. See text accompanying note 40 infra.

8 Jenkins v. State, - Del. -, 230 A.2d 262 (1967) ; People v. Worley, - Ill. 2d - 227 N.E.2d 746 (1967); State v. Vigliano, - N.J. -2 232 A.2d 129 (1967); People v. La Belle, 53 Misc. 2d 111, 277 N.Y.S.2d 847 (County Ct. 1967). See also Commonwealth v. Brady (O. \& T. of Q.S. of Crawford County, July 17, 1967), in The Legal Intelligencer, Aug. 16, 1967, at 1, col. 1.

9 The Supreme Court enumerated the following procedures in Miranda: the accused must be advised (1) that he has a right to remain silent; (2) that anything he may say can be used against him; (3) that he has a right to the presence of counsel during the interrogation; and (4) that if he cannot pay an attorney, one will be appointed for him prior to any questioning. Provision was also made for knowing waiver of these rights, and for their re-effectuation should there be any indication that the accused wishes to discontinue the interrogation. 384 U.S. at 444-45.

$10 I d$. at 467.

$11 I d$. at $444,468,479$.

12378 U.S. 478 (1964). The Court held that once the police focus on the accused, he must be advised of his privilege to remain silent and he must be allowed to consult with an attorney upon request. The Court in Miranda further explained what was intended in Escobedo. 384 U.S. at 444 n.4.

13 The Court in Miranda indicated that the privilege against self-incrimination may be violated even if the accused's statements are not entered into evidence against him at trial :

Today. . . there can be no doubt that the Fifth Amendment privilege is available outside of criminal court proceedings and serves to protect persons 
surrounding the incriminating statements in an effort to determine if the confession was given freely. ${ }^{14}$

The majority in Johnson, honoring the reliance of police and courts on the old standards and conscious of the havoc which full retroactivity could play with the administration of justice, ${ }^{15}$ limited the retroactivity of Miranda and Escobedo to the decided cases themselves. In setting the time of trial as the criterion of Miranda's applicability, however, the Court failed to consider what should be done in retrials granted on grounds other than Miranda. The ultimate determination of this issue must reflect consideration of the different values which the Miranda and Johnson decisions sought to protect.

Both courts ordering Miranda applicable in retrial and courts denying its applicability have found support in the wording of the Johnson decision. The statement in Johnson that Miranda shall apply only to "trials" begun after Miranda was decided, ${ }^{18}$ taken alone, would seem to indicate that Johnson demands that the exclusionary rule be applicable in retrial. ${ }^{17}$ The courts which accept this view conceive of

in all settings in which their freedom of action is curtailed in any significant way from being compelled to incriminate themselves.

384 U.S. at 467 . A more narrow interpretation is given by Chief Justice Traynor of the California Supreme Court:

The basis for the warnings required by Miranda is the privilege against seifincrimination ...., and that privilege is not violated when the information elicited from an unwarned suspect is not used against him.

People v. Varnum, - Cal. 2d - -, 427 P.2d 772, 775, 59 Cal. Rptr. 108, 111 (1967). However, Mr. Justice Peters, dissenting, thought that whether or not the statement is introduced at trial, Escobedo and Miranda recognize a "right to privacy . . the moment interrogation starts." Id. at -, 427 P.2d at 778, 59 Cal. Rptr. at 114 .

14 Haynes v. Washington, 373 U.S. 503, 514 (1963) ; State v. Vigliano, - N.J. $\ldots, 232$ A.2d 129, 136 (1967); see Davis v. North Carolina, 384 U.S. 737, 740 (1966) :

The standard of voluntariness which has evolved in state cases under the Due Process Clause of the Fourteenth Amendment is the same general standard which applied in federal prosecutions-a standard grounded in the policies of the privilege against self-incrimination. Malloy $v$. Hogan, 378 U.S. 1, 6-8 (1964).

In Malloy v. Hogan the Court held that "the Fifth Amendments exception from compulsory self-incrimination is also protected by the Fourteenth Amendment against abridgement by the States." 378 U.S. at 6 . The majority opinion of Mr. Justice Black thus asserted that this portion of the fifth amendment is "incorporated" in the fourteenth amendment and must be heeded by the states. Mr. Justice Harlan, dissenting, disagreed with the "incorporation" doctrine, seeing no need for the incorporation since adequate protection is afforded the accused under the due process clause alone. 378 U.S. at 21-27. See also Pointer v. Texas, 380 U.S. 400 (1965) (Black, J.); $i d$. at 408 (Harlan, J., dissenting). For further discussion of the voluntariness test, see text accompanying notes 61-64 infra.

15384 U.S. at 731 . For discussion of these issues, see text accompanying notes 40-41, 50-51 infra.

16 See text accompanying note 3 supra.

17 People v. La Belle, 53 Misc. 2d 111, 113, 277 N.Y.S.2d 847, 849 (County Court 1967) (dictum). This would mean that even though the specific procedural safeguards were enunciated for the first time after the time of the in-custody interrogation of the accused, statements made by him will be inadmissible in evidence against him if any of the safeguards have not been observed, or if the State cannot demonstrate that equivalent protective measures have been taken. Such is already the situation in cases in which the interrogation occurred before Miranda, but the initial trial began after Miranda. 
the term "retrial" as subsumed in the term "trial." In some states this concept is articulated in statutes which define a retrial as an entirely new beginning; the courts of two of those states have relied upon these statutes as support for holding Miranda applicable on retrial. ${ }^{18}$

Other parts of the Johnson opinion, however, create some doubt whether the Court intended this interpretation of the word "trial." The Court states, for example, that "Future defendants will benefit fully from our new standards governing in-custody interrogation, while past defendants may still avail themselves of the voluntariness test." 19 This reference to "past" and "future" defendants is inconclusive. If the position is accepted that when a new trial is granted, it "shall proceed in all respects as if no former trial had been had," the fact that the defendant was also a prior defendant would seem to be irrelevant. Several courts, however, have taken the position that the availability of a "second chance" does not obviate the existence of the first trial. In the words of one court, such a defendant "is certainly not a future defendant, having been one well over two years prior to Miranda and the Supreme Court could not have had those in his position in mind." 20

There is other language in the Johnson decision, however, which would tend to support the classification of a defendant in a retrial as a "past" defendant. It was the precise holding of the Court that "Escobedo and Miranda should apply only to cases commenced after those decisions were announced." 21 The term "case" usually incorporates the entire history of the judicial proceedings against the accused. Accordingly, the Supreme Court of New Jersey, holding Miranda inapplicable in retrial, understood "cases commenced" to refer to cases in which the first judicial step was taken after Miranda. ${ }^{22}$ They urged that their view

accords with a commonplace of the criminal law in this country, i.e., an order for a new trial as an incident of a reversal of a conviction on appeal simply amounts to a continuance of the same case looking toward a final judgment of either acquittal or conviction. ${ }^{23}$

Under this view, the defendant in a retrial is a "past defendant," and therefore, under Johnson, does not have the benefit of the Miranda

18 State v. Brock, 101 Ariz. 168, 172, 416 P.2d 601, 605 (1966) (citing ArIz. R. CRIN. P. 314: "the new trial shall proceed in all respects as if no former trial had been had."); People v. Doherty, - Cal. 2d -, -, 429 P.2d 177, 185, 59 Cal. Rptr. 857, 865 (1967) (citing 50 CAL. PENAL CODE $\$ 1180$ : "The granting of a new trial places the parties in the same position as if no trial had been had.").

I9 384 U.S. at 732 (emphasis added). 1967).

20 People v. La Belle, 53 Misc. 2d 111, 113, 277 N.Y.S.2d 847, 849 (County Ct.

21384 U.S. at 733 (emphasis added).

22 State v. Vigliano, - N.J. -, -, 232 A.2d 129, 137. (1967).

23 Id. 
exclusionary principle on retrial. Even if state statutes declare a retrial to be a new beginning, they are not controlling. The interpretation of the word "trial" is properly ascertained from the Johnson opinion itself, not from an outside source. ${ }^{24}$

The basic argument for the non-retroactivity of Miranda lies in the concern of the Johnson court for police reliance and the potential burden on the administration of justice. ${ }^{2 \pi}$ These "countervailing interests" 26 were balanced against the purpose of the Miranda rule and the availability of other safeguards. ${ }^{27}$ Although the Court did not deny the possibility of past or pending cases in which "tainted" confessions have been used, the discrimination against those defendants was thought to be outweighed by "the exigencies of the situation." 28 If the "countervailing" factors are as significant in the retrial situation, Johnson suggests that the application of Miranda on retrial is not demanded. However, because this issue was not in the direct purview of the Court's decision, there may be factors peculiar to the retrial situation which could suggest differing application of Miranda to retrials and to other non-final judgments.

The reliance of public officials on standards acceptable prior to the Escobedo and Miranda decisions is emphasized throughout the Johnson opinion: ${ }^{29}$

Law enforcement agencies fairly relied on these prior cases, now no longer binding, in obtaining incriminating statements during the intervening years preceding Escobedo and Miranda. This is in favorable comparison to the situation before Mapp v. Ohio . . . , where the States at least knew that they were constitutionally forbidden from engaging in unreasonable searches and seizures under $W$ olf $v$. Colorado 30 1967).

24 People v. La Belle, 53 Misc. 2d 111, 114, 277 N.Y.S.2d 847, 850 (County Ct.

25384 U.S. at 731-33.

26 See Stovall v. Denno, 388 U.S. 293, 299 (1967).

27 Johnson v. New Jersey, 384 U.S. 719, 729( 1966).

In Stovall $v$. Demo, when considering the extent to which the new constitutional rules on "lineups" should be applied retroactively, the Court noted that

The criteria guiding resolution of the question implicate (a) the purpose to

be served by the new standards, (b) the extent of the reliance by law en-

forcement authorities on the old standards, and (c) the effect on the administration of justice of a retroactive application of the new standards.

388 U.S. at 297. See text accompanying notes $45-47$ infra.

28384 U.S. at 727, 728-29. See Stovall v. Denno, 388 U.S. 293, 299. But see id. at 304 (Black, J., dissenting).

29 But see People y. Doherty, - Cal. 2d -, -, 429 P.2d 177, 183, 59 Cal. Rptr. 857,863 (1967) (denying that reliance was important in Johnson).

30384 U.S. at 731. The Supreme Court, in Linkletter v. Walker, 381 U.S. 618 (1965), held that the Mapp decision would not be retroactive. Mapp, however, was held to be applicable to all cases not yet final on the date when Mapp was decided. The disparity between Linkletter and the ruling in Johnson (that Miranda would not apply to cases not yet final at the time of Miranda) can be explained on the ground 
. . Law enforcement officers and trial courts will have fair notice that statements taken in violation of these standards may not be used against an accused. Prospective application only to trials begun after the standards were announced is particularly appropriate here. Authorities attempting to protect the privilege have not been apprised heretofore of the specific safeguards which are now obligatory. Consequently they have adopted devices which, although below the constitutional minimum, were not intentional evasions of the requirements of the privilege. ${ }^{31}$

Assuming that the stated reliance was justifiable, ${ }^{32}$ it has been argued that this reliance was sufficient reason in Johnson for not applying Miranda to non-final cases. ${ }^{33}$ From this premise, the Supreme Court of New Jersey reasoned that "such reliance should have the same operative effect if the appeal results in a reversal and an order for a new trial" as it would if there were no reversal. ${ }^{34}$

The reliance argument is persuasive when a court's decision would not only conflict with a party's anticipations, but also would place that party in a disadvantaged position because of his reliance. ${ }^{35}$ It is doubtful that validation of past official conduct in itself can justify the nonretroactivity decision of Johnson. It might be argued that a retroactive decision impairs public confidence in the police and thus hampers law enforcement efficiency, but there is no indication in Johnson of a fear of criticizing the police. It appears far more likely that the Court in Johnson was concerned primarily with the burden on the administration of justice which would follow a decision that Miranda be applied retroactively. ${ }^{36}$

that the Court had applied the rule of Mapp to non-final decisions prior to the Linkletter decision and was not free to discontinue this practice. Prior to Johnson the Court had not applied the rule of Miranda to non-final cases (except to the overruling cases themselves) and was free not to apply Miranda to non-final cases. People v. Rollins, 65 Cal. 2d 681, 689-90, 423 P.2d 221, 227-28, 56 Cal. Rptr. 293, 299-300 (1967). On the advisability of drawing the line at the time of trial, see People v. Rollins, $i d$. at 688 n.7, 423 P.2d at 226 n.7, 56 Cal. Rptr. at 298 n.7 (1967).

31384 U.S. at 732-33.

32 See State v. Vigliano, - N.J. - - , - 232 A.2d 129, 137 (1967); State v. Shoffner, 31 Wis. $2 \mathrm{~d}$ at $446-47,143$ N.W.2d at 475 (dissenting opinion). But see People v. Rollins, 65 Cal. 2d at 687, 423 P.2d at 225, 56 Cal. Rptr. at 297 (1967). In light of the Escobedo decision, it is arguable that as the date of the overruling decision approached, law enforcement officers could not have fairly relied on past standards since the probability of a change in standards was great.

33 State v. Vigliano, - N.J. - - - 232 A.2d 129, 137 (1967). This proposition is questionable, however, since reliance was given no weight by the Johnson court for those cases to be tried for the first time after Miranda and in which the interrogation process preceded the date of Miranda. See text accompanying note 51 infra. 34 State v. Vigliano, - N.J. - , - , 232 A.2d 129, 137 (1967).

35 There is significance to a party's reliance, even when there is no injury caused by such reliance, if the "symbol" of justice and stability in the law would be jeopardized. For a discussion of the importance of the symbolic function of the law, see Mishkin, supra note 4 , at $62-76$.

36 Moreover, the burden on the administration of justice is worthy of consideration because of the justifiability of the reliance. 
The essential concern in Johnson was the fear that retroactive application of Escobedo and Miranda would seriously disrupt the administration of our criminal laws. It would require the retrial or release of numerous prisoners found guilty by trustworthy evidence in conformity with previously announced constitutional standards. ${ }^{37}$

The Court articulated a similar apprehension in Stovall v. Denno, where a new rule ${ }^{38}$ involving the constitutional requirements for identification "line-ups" was held to be prospective in application. "At the very least, the processing of current criminal calendars would be disrupted while hearings were conducted to determine taint, if any, in identification evidence. . . ." 39

Thus, the Court seems to have been deeply concerned about the burden of "correcting" completed proceedings. However, even though a case on retrial is a non-final case, and non-final cases were explicitly excluded from the area of Miranda's necessary operation by the Johnson Court, the retrial situation has several distinguishing aspects.

First, since the case must be retried anyway, there will be no "flood of litigation" problem in requiring that Miranda be applied in the retrial. ${ }^{40}$ Thus, what was probably the major factor in the Court's choice of "prospectivity" in Johnson is absent in the instant situation. Also, if the prosecution feels it will be unable to obtain convictions when Miranda is applied, it may choose not to prosecute and further lessen the existing burdens on the court calendar. The resulting burden on society of releasing some defendants "found guilty by trustworthy evidence," ${ }^{41}$ will be less onerous than that which would have occurred if Miranda had been held fully retroactive; the number of defendants who will be able to utilize Miranda in retrials will be far smaller than the potential group which could have raised it had it been applied retroactively in general.

There is a second factor which distinguishes the retrial situation from final and other non-final cases. Insofar as there must be a new trial, it offends one's sense of justice to have simultaneous trials in adjacent courtrooms conducted under different rules. It is disturbing to see one defendant tried under a "second-best" standard, while another defendant tried concurrently receives the full benefit of the principles of Miranda. ${ }^{42}$ To deny application of Miranda in this

37384 U.S. at 731.

38 See text accompanying notes $46-47$ infra.

39388 U.S. at 300.

40 See People v. Doherty, - Cal. 2d -, -, 429 P.2d 177, 183-84, 59 Cal. Rptr. $857,863-64$ (1967).

41 See text accompanying note 37 supra.

42 As one court has concluded, "the 'guidelines' suggested by the Chief Justice, were not available at the time of trial and we see no reason why those principles 
manner would create apparent inconsistency, impairing the symbol of justice as an impartial arbiter. ${ }^{43}$ The Supreme Court has already delineated one area in which the reliance of public officials and the burden on the administration of justice are not to be allowed overriding significance: cases first coming to trial after Miranda and in which the interrogation occurred before that decision. These are trials which must be conducted anyway. To have held Miranda inapplicable to them, would have necessitated non-uniformity of judicial treatment. ${ }^{44}$

However, these distinguishing aspects of the retrial situation do not necessarily compel application of Miranda in retrial. First, the boundaries of the prospective ruling in Stovall $v$. Denno suggest that under certain circumstances there is no impropriety in applying a former constitutional standard in trials which take place after a new standard is announced. In Stovall, the Court held that the principles of United States v. Wade ${ }^{45}$ and Gilbert v. California, ${ }^{46}$ requiring

the exclusion of identification evidence which is tainted by exhibiting the accused to identifying witnesses before trial in the absence of his counsel, ${ }^{47}$. . . affect only those cases and all future cases which involve confrontations for identification purposes conducted in the absence of counsel after this date. ${ }^{48}$

The test of applicability is thus not whether the trial occurs after the date of the overruling decision, as in Johnson, but whether the identification confrontation ("line-up") takes place after the decision. As a result, there will be cases tried after the date of the Wade-Gilbert decision in which the new rule will not apply because the confrontation occurred prior to that date.

If the "second-best" standard for identification procedures can be applied at the same time that the new standard is being applied,

should not be applied on the new trial of this cause." Gibson v. United States, 363 F.2d 146, 148 (5th Cir. 1966). But see note 50 infra.

At the same time that it seems inconsistent to deny the retrial defendant the benefit of Mirasda, while giving that advantage to original-trial defendants, it seems inconsistent to give that benefit to the retrial defendant and not to a defendant tried

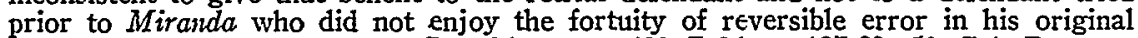
trial. People v. Doherty, - Cal. $2 \mathrm{~d}$ at $\rightarrow 429$ P.2d at 187-88, 59 Cal. Rptr. at 867-68 (1967) (concurring opinion). It has also been argued that it is "neither logical nor reasonable that the retrial should be conducted under rules different from those prevailing when the cases were tried for the first time." Jenkins v. State, Del. _- -230 A.2d 262, 274 (1967). See State v. Brock, 101 Ariz. at 175-76, 416 P.2d at 608-09 (dissenting opinion).

43 See note 35 supra.

44 In the situation of a defendant coming to trial for the first time after Miranda who was interrogated prior to Miranda, the proximity of the interrogation process to the trial diminishes the evidentiary burden facing prosecutors and public officers. For the importance of the evidentiary burden, see text accompanying note 51 infra. 45388 U.S. 218 (1967).

46388 U.S. 263 (1967).

47 Stovall v. Denno, 388 U.S. 293, 294 (1967).

48 Id. at 296. 
there should be less conceptual difficulty in applying the "voluntariness" standard of confession admissibility at the same time that Miranda is being applied. The purpose of the new rule in Wade and Gilbert was to prevent prejudice to the defendant and to avoid mistaken identifications. These are concerns which affect the reliability of the guiltdetermining process. In Miranda, reliability was not as much of an issue ${ }^{49}$ as was the protection of the dignity of the accused and the desire not to force a defendant to convict himself. If, in a narrow range of cases, the Court is willing to suspend application of a higher standard which enhances the reliability of the system, it should be far less disturbing to suspend application of Miranda where the main consideration is the procedural integrity of the system. Thus, the argument that "second-best" constitutional standards should not be used concurrently with best standards is not conclusive in the retrial situation. ${ }^{50}$

Second, the burden on the administration of justice is not eliminated completely merely because there must be a new trial regardless of Miranda. Evidence previously foregone in reliance upon former standards of confession admissibility now must be gathered to fill the void left by the excluded confession. When the same problem was presented in Stovall, the Court was careful to note this as a "countervailing interest:" "Doubtless, too, inquiry would be handicapped by the unavailability of witnesses and dim memories." ${ }^{51}$

In this regard, the retrial situation is distinguishable from a postMiranda original trial after a pre-Miranda interrogation, a case in which, as noted above, the Court gave Miranda retroactive application. In the latter case, the evidence which the police must compile is still likely to be "fresh," and it can be expected that before the trial these officials will have an opportunity to acquire the needed evidence. In the retrial situation, the police face a far more difficult task in attempting to compensate for the inadmissibility of the confession since

49 The Court in Miranda mentioned unreliability of coerced confessions only in a footnote. 384 U.S. at 455 n.24.

50 The Johnson opinion explicitly left open to the states the freedom to apply Miranda more retroactively than was demanded by Johnson. 384 U.S. at 733. Certainly if a state already has applied Miranda to other non-final cases, disregarding the burden on the administration of justice, it would only be consistent to apply Miranda in the retrial situation as well.

51388 U.S. at 300 . But see People v. Rollins, 65 Cal. 2d at 696, 423 P.2d at $232,56 \mathrm{Cal}$. Rptr. at 304 (dissent), arguing that Miranda should be applied to all cases not yet final at the time of Miranda, even though inevitably "hardships to the police would result":

The burdening of the administration of criminal justice is a price we must

pay to enforce our Bill of Rights, and a price we should pay without hesitation.

The powers of governments, and that includes the police, are limited by the

Bill of Rights. When such rights are invaded we must repulse such invasion

The Court in Miranda likewise asserts that the fifth amendment privilege "cannot be abridged" to satisfy "society's need for interrogation," 384 U.S. at 479, or to lessen the labors of government. Id. at 460 . 
the trial is further removed in time from the investigation. The unavailability of evidence may necessitate dismissals or acquittals, should Miranda be applied.

The interest of society here cannot be dismissed easily. It might be argued that by virtue of the establishment of stricter standards in Miranda, the Court has balanced society's interest in protection and safety against an accused's constitutional privileges, and has chosen to run the risk that people who have committed crimes will avoid imprisonment. However, in the normal case where Miranda will govern, the police will have had prior notice of the constitutional requirements and will have the opportunity to gather the evidence necessary to convict the guilty. In the retrial situation, through their justifiable reliance on the admissibility of confessions, the police have foregone the opportunity to gather such evidence and society's interest cannot be protected. Thus, the Miranda balance does not necessarily control this situation.

In determining whether Miranda should be applied in retrials, the burden imposed by the evidentiary difficulties must be measured against the adequacy of the alternative standard, the voluntariness test. Consideration of alternative devices for protecting the accused was noted as a legitimate concern in Johnson:

We are thus concerned with a question of probabilities and must take account, among other factors, of the extent to which other safeguards are available to protect the integrity of the truth-determining process at trial..$^{52}$

The greater the gap between the degree of protection afforded by Mirand $a$ and that afforded by the voluntariness test, the greater is the pressure to override the factors of police reliance, evidentiary burden and society interest, and to apply Miranda in retrial.

The fact that stricter rules were promulgated in Miranda indicates the Court's dissatisfaction with the voluntariness test. ${ }^{53}$ Modern police practice "is psychologically rather than physically oriented." 54 The psychological effect of a potentially coercive situation is difficult for the trial judge and jury to measure under the voluntariness test. ${ }^{55}$ The

52384 U.S. at 729.

53 Referring to the Miranda case and its companion cases, the Miranda Court said that they "might not find the defendant's statements to have been involuntary in traditional terms." 384 U.S. at 457.

54 Miranda v. Arizona, 384 U.S. 436, 448 (1966).

55 The line between proper and permissible police conduct and techniques and methods offensive to due process is, at best, a difficult one to draw, particularly in cases such as this where it is necessary to make fine judgments as to the effect of psychologically coercive pressures and inducements on the mind and will of an accused.

Haynes v. Washington, 373 U.S. 503, 515 (1963). 
Court in Miranda thought that many subtle pressures could be eliminated if those accused were explicitly told of their rights. Estimates of an accused's understanding of his constitutional privileges in the absence of specifically being informed of them can only be speculative. ${ }^{56}$ Judicial problems in reviewing the effect of these practices were compounded by the difficulty of litigating what actually happened in the stationhouse. $^{57}$ The defendant's primary means of showing coercion was to match his testimony against that of the interrogating officers. Miranda sought to eliminate such "swearing contests" by ensuring that the individual knew he has the right not to confess and by placing a lawyer in the stationhouse as an informed observer. ${ }^{58}$

However, neither Miranda nor Johnson indicated that every statement acquired when the procedural safeguards are not followed is necessarily involuntary. ${ }^{59}$ The Court was not denying "past defendants" whose involuntary confessions had been used against them the opportunity for redress. On the contrary, the Court specifically noted that they are entitled to a "full and fair hearing," 60 but that the "exigencies of the situation" demand that this hearing be governed by the voluntariness test instead of the Miranda rules. The issue at hand is whether the lesser "exigencies" presented by retrials also justify employment of the lower standard.

In view of the effect Miranda itself will have on the voluntariness standard, it is difficult to assess how much less protection will be provided by the "voluntariness test" than by the Miranda rules. The Court in Johnson noted that:

Prisoners may invoke a substantive test of voluntariness which, because of the persistence of abusive practices, has become increasingly meticulous through the years. . . . That test now takes specific account of the failure to advise the accused of his privilege against self-incrimination or to allow him access to outside assistance. ${ }^{61}$

The standards of the voluntariness test thus are "evolving" standards, ${ }^{62}$ flexible enough to take into account the concerns pointed out by

56 Miranda v. Arizona, 384 U.S. 436, 468-69, $471-72$ n.43 (1966).

57 See Stovall v. Denno, 388 U.S. 293, 298 (1967), where one of the reasons given for the rule announced in Wade and Gilbert was "the likelihood that the accused will often be precluded from reconstructing what occurred and thereby from obtaining a full hearing on the identification issue at trial."

58 Cf. Stovall v. Denno, 388 U.S. 293, 298-99 (1967) (dictum).

59 See Commonwealth v. Brady (O. \& T. of Q.S. of Crawford County, July 17, 1967) in The Legal Intelligencer, Aug. 16, 1967, at 4, col. 6.

60384 U.S. at 730.

61 Id. See Davis v. North Carolina, 184 U.S. 737, 740 (1966) ; United States ex rel. Pierce v. Pinto, 259 F. Supp. 729, 731 (D.N.J. 1966) ; People v. La Belle, 53 Misc. 2d 111, 113, 277 N.Y.S.2d 847, 849 (County Ct. 1967). The Miranda Court, in fact, asserted that their holding was not an "innovation" in the field. 384 U.S. at 442 .

${ }^{62}$ See Davis v. North Carolina, 384 U.S. 737, 740 (1966), a post-Miranda decision in which defendant did prevail under the "evolved" voluntariness test. 
Miranda. ${ }^{63}$ Under this "evolved" standard, the contrast between the treatment of the retrial defendant and the original-trial defendant will be diminished, society's interest will be protected and the harsh evidentiary burdens will be averted.

If this position is accepted - that the contrast between the treatment of the original-trial defendant under Miranda and of the retrial defendant under the "second-best" standard is not untenable in the light of the exigencies of the situation-it remains to be asked what could be gained by application of Miranda in retrial. The rules of Miranda were promulgated in order to deter certain police conduct which tended to jeopardize the privileges of the accused. The rules also made explicit what behavior was required of police. It is now too late to deter the behavior of police with regard to the retrial defendant; if the police conduct fell below the standards announced in Miranda, the dignity of the individual has already suffered. Application of Miranda could prevent this injury from culminating in self-incrimination at trial. However, application of the voluntariness test could at least prevent this in most obvious cases of coercion. ${ }^{64}$ Consequently, the circumstances of the retrial situation make the use of the voluntariness test preferable to application of Miranda on retrial.

13 See the dissenting opinion of Mr. Justice Clark in Miranda v. Arizona, 384 U.S. at 503 (1966).

64 In view of the hardships incumbent upon applying the exclusionary principle of Miranda, several state courts have preferred application of the voluntariness test as it is described by the United States Supreme Court in the Davis case. See, e.g., State v. Vigliano, - N.J. -, 一, 232 A.2d 129, 138 (1967). 